\title{
KEY DRIVERS OF BRAND LOYALTY AMONG MALAYSIAN SHOPPERS: EVIDENCE FROM A JAPANESE FASHION RETAILER
}

\author{
Jasmine A.L. Yeap ${ }^{1 *}$, T. Ramayah ${ }^{1}$, and Emily H.T. Yapp ${ }^{2}$ \\ ${ }^{1}$ School of Management, Universiti Sains Malaysia, 11800 USM Pulau Pinang, Malaysia \\ ${ }^{2}$ Labuan Faculty of International Finance, Universiti Malaysia Sabah, \\ Labuan International Campus, 87000 Labuan, Sabah, Malaysia \\ *Corresponding author: jasmine@usm.my
}

Published online: 21 December 2018

To cite this article: Yeap, J.A.L., Ramayah, T., and Yapp, E.H.T. (2018). Key drivers of brand loyalty among Malaysian shoppers: Evidence from a Japanese fashion retailer. Asian Academy of Management Journal, 23(2), 1-24. https://doi.org/10.21315/ aamj2018.23.2.1

To link to this article: https://doi.org/10.21315/aamj2018.23.2.1

\begin{abstract}
Due to the uncertain, changing landscape and challenges in the fast-moving fashion retailing market, fashion retailers have to find their way to stay competitive and survive in the market. One of the ways is through effective use of branding. Focusing on a currentlyleading, Japanese fast fashion retailer (Uniqlo), this research sought to determine the branding attributes which could lead to the formation of brand loyalty among customers. The Service Brand Verdict Model (SBVM) served as the basis for this study's research model. Through the partial least squares (SmartPLS 3.2.6) analysis on 309 Uniqlo customers, the results showed that merchandise, value-for-money, feelings, self-image congruence and uncontrolled communications are significant aspects that contribute to building brand loyalty among customers. In building intense and active loyalty among customers, both tangible and rational aspects of a brand as well as the imagery and emotional aspects of it need to be integrated in strategic branding decisions.
\end{abstract}

Keywords: brand evidence, brand hearsay, brand loyalty, Japan, retail clothing

(C) Asian Academy of Management and Penerbit Universiti Sains Malaysia, 2018. This work is licensed under the terms of the Creative Commons Attribution (CC BY) (http://creativecommons. org/licenses/by/4.0/). 


\section{INTRODUCTION}

Fashion retailing is a fast-moving industry characterised by boundless, increasing competition. It has been frequently referred to as an uncertain, changing, and challenging landscape. As a consequence, fashion retailers have to frequently find ways to sustain their presence in the marketplace while remaining profitable at the same time. In Malaysia, the fashion retailing industry has demonstrated positive performance over the last few years (Euromonitor International, January 2017). Like other consumers worldwide, Malaysians are becoming more demanding, more discerning, and less predictable in their consumption behaviour. Malaysians, especially the millennial consumers, are very image-conscious. They are considered as heavy consumers, especially on apparel and personal accessories, and this has contributed to the strong performance of retail channels.

From a gender perspective, menswear showed a value growth of $6 \%$ in 2016 while womenswear showed a value growth of 5\% (Euromonitor International, March 2017a, 2017b). This statistic indicates that men are also paying more attention towards their appearances. From a fashion retailer perspective, Malaysians have been and are projected to continue paying more attention towards international fashion brands. Due to that, major fashion retailers such as Uniqlo, H\&M, CottonOn, Zara, and Mango are still expanding their stores across the nation rapidly to raise their brand awareness (Euromonitor International, January 2017). Furthermore, to stimulate consumer demand and encourage consumers to spend, fashion retailers have resorted to implementing aggressive marketing strategies.

In order to remain viable in the marketplace, it is pertinent that fashion retailers understand the key drivers of retail success. One of these key drivers includes effective branding. If successful, a brand can serve as a company's strongest weapon and best guarantee of corporate survival (Temporal, 2000). However, all too often companies either do not fully appreciate the power of their brands or that they fall short in executing strong branding strategies. According to Berry (2000), branding is seen as a key success factor for service organisations and that it must be seen as a "cornerstone of services marketing". To consumers, brands could convey rich meaning and connotation. Therefore fashion retailers should take the advantage to build a relationship between themselves and their customers. When a customer has enhanced strong relationship with the brand, this could drive the customer to be loyal towards the brand.

Brand loyalty in this study is defined as "a deeply held commitment to rebuy or repatronise a preferred product/service consistently in the future, thereby causing repetitive same brand or same brand-set purchasing, despite situational influences 
and marketing efforts having the potential to cause switching behavior" (Oliver, 1999 , p. 34). Brand loyalty can be approached from two main perspectives namely the behavioural approach and the attitudinal approach (Jacoby \& Chestnut, 1978). Behavioural loyalty is based on actual purchase behaviour (overt behaviour) and also known as actual past behaviour (Jacoby \& Chestnut, 1978). On the other hand, attitudinal loyalty is based on preference or intention to behave but it is not an actual purchase behaviour (Jacoby \& Chestnut, 1978) rather the overall feelings of the consumer towards the entity and his or her intention to purchase (Schiffman \& Kanuk, 2014). The outcome of brand loyalty is believed to drive brand profitability (Marticotte, Arcand, \& Baudry, 2016). For example, previous researchers such as Reichheld (1996) had identified that brand loyal customers are more willing to pay for the brand because the uniqueness value of the brand cannot be substituted by other brand-name. Similarly, brand loyalty could lead to a greater market share when loyal customers keep repurchasing the brand. Moreover, because of the loyalty, positive word-of-mouth will also be spread either through online or offline environment (Wallace, Buil, \& Chernatony, 2014). All the above outcome is closely associated with the increase of brand equity. For this reason, superior brand evaluation by the customer is very important.

\section{Objective of the Study}

Japanese retail brands have started gaining recognition and popularity among consumers worldwide, in particular, the fashion brand Uniqlo. Beginning with just one store in the suburbs of Japan in 1984, Uniqlo today has established itself as one of the most recognised and admired fashion brands in the world with more than 1,300 stores in 15 countries throughout Asia, London, Europe, and the USA. Uniqlo has become the envy of retailers worldwide with its brand value of US\$4.16 billion surpassing US rival, the Gap's, brand value of US\$3.92 billion (Interbrand, 2014).

As a fairly new entrant to the Malaysian market, Uniqlo has successfully gained awareness among consumers of all ethnicities and age groups within a short period of time. With Uniqlo's slogan "Made for All", it offers a wide range of "lifewear" (clothing as how the company calls it) that is high-quality, functional, innovative, and affordable for men, women, and kids. Furthermore, Uniqlo is not an ordinary fashion brand that offers only fashion trends but it is also a fashion brand that offers clothing innovation through product innovations such as HeatTech and AlRism.

This has prompted its rapid expansion within the last few years ever since entering the Malaysian market circa 2010. As of August 2017, there are 41 Uniqlo stores spread out across both East and West Malaysia (https://www.uniqlo.com/my/ 
store). What makes Malaysian consumers attracted to and continue to patronise this Japanese retail brand? Accordingly, this study was driven by the aim of acquiring a deeper understanding on the way in which Malaysian consumers make sense of and evaluate Japanese retail brands particularly Uniqlo. This study strived to uncover the aspects or attributes of branding which were meaningful to consumers during their experience with Uniqlo that led them to their loyalty towards the brand.

In other words, the crux of this study is simple - to identify the key drivers of brand loyalty in the context of retailing by focusing on one popular Japanese retail brand. To do so, we applied and modified the Service Brand Verdict Model (SBVM) developed by Grace and O'Cass (2005). The SBVM which was originally constructed as sufficient enough to be applied in most service settings, should in fact deserve more attention from scholars in the retailing context. The retailing industry has now evolved into an era dominated by single brand retailers such as Uniqlo whereby all aspects of branding need to be considered prudently should one aspire to survive in this industry. The SBVM with its simple premise as well as holistic coverage of brand aspects can serve as an appropriate model to study brand loyalty in single brand retailers. Grace and O'Cass (2005) and Krystallis and Chrysochou (2014) may have empirically verified the SBVM, however more studies are needed to apply the SBVM in different settings. In this case, the SBVM was applied in the context of single brand stores of foreign brand origin, an area which is still in want of research studies.

Furthermore, the application of SBVM in this study was modified in that only the impact of branding aspects on brand loyalty were examined. The main intent was to examine how brand loyalty can be developed using the most parsimonious of branding variables as upheld in the SBVM. In the midst of complicated models consisting of conditional (third) variables, oftentimes it is the basic and most uncomplicated of things studied, grounded on the principle of parsimony that are able to deliver simple but deep insights. This study attempts to fulfill that neglected void for straightforward and direct studies.

\section{Significance of the Study}

Focusing on retail brand evaluations held by Malaysian consumers is crucial given that retailing is an important industry for Malaysia. It is a significant contributor to the economic development of the country. The wholesale and retail sector is the fourth biggest contributor to Malaysia's gross national income (GNI) among the 12 National Key Economic Areas, contributing to a growing share of gross domestic product (GDP) between 2010 and 2015 which grew 30\% from RM797.3 
billion to RM1.13 trillion (Economic Transformation Programme, 2015). Retailing also attracts tourism which is another major income generator for the country. Since 2014, tourists' spending in the retail sector has contributed over RM21.6 billion to the country's economy. This has made Malaysia the 10th most attractive countries for retailers (Economic Transformation Programme, 2014). Furthermore, Malaysia's Private Consumption accounted for an average share of $47.1 \%$ or its nominal GDP from March 1991 to September 2017 (CEIC, 2017). To achieve the 2020 GNI target, the retail sector would be a key driver of domestic consumption, which in turn will lead to Malaysia's economic growth. Therefore, there is a need for attractive retail brands that can boost domestic consumption while at the same time stimulate tourist expenditure. For this reason, studies such as this would be beneficial in helping aspiring as well as struggling retailers, both small and large, on the ways of creating powerful brands by drawing lessons from one of the world's dynamic, leading retail brands, i.e. Uniqlo. When most of the big brands such as Old Navy and Banana Republic are closing their stores overseas and concentrating on the US market, Uniqlo seems to be going the opposite direction where they continue on with their plans for global expansion (Melody, 2016). As in Malaysia, the fashion and design industry has a great potential to grow (Melody, 2016).

\section{LITERATURE REVIEW}

\section{Theoretical Foundation}

Several theories had been proposed by previous researchers (Chernatony \& Riley, 1998; Berry, 2000) in understanding branding from various perspectives and in different contexts of study. However, none of these theories help to explain how customers evaluate and respond towards a brand. For example, Berry (2000) proposed a Service-Branding Model on the analysis of existing matured brands but the constructs (servicescapes, word-of-mouth communications, publicity, and advertising) had not been tested empirically. As for Chernatony and Riley (1998), their study only focused on branding experts without involving the end users. Due to this limitation, the SBVM was proposed to explain how consumers evaluate and respond to the brand. The SBVM was proposed by Grace and O'Cass in 2005. According to this model, it could provide a better picture of service branding which had not been done so in previous research. Furthermore, the nature of service brand which is based on experience and delivered by employees could contribute to a different outcome as compared to physical goods. Due to this, the dimensions of this model are relevant to consumers' perspective on service brands and more importantly in Japanese brand name, Uniqlo. 
In the SBVM, Grace and O'Cass (2005) identified two key constructs which are brand evidence and brand hearsay. Brand evidence refers to the brand attributes that are being experienced by the consumer during the pre-purchase as well as the consumption stage. The dimensions in brand evidence consist of brandname, merchandise, value-for-money, servicescape, employee service, feelings, and self-image congruence. These dimensions will influence customers' brand evaluation. As for brand hearsay, it consists of two types of communication which are controlled and uncontrolled communications. Similar to brand evidence, these communications will be received by customers prior to the purchase and it will influence customers' evaluation towards the brand. Given its merits, the SBVM served as the basis for this study's research framework.

\section{Development of Research Framework and Hypotheses}

Brand name is very important for a product or a service to be successful in the market. Brand name is defined as a "multidimensional construct consisting of functional, emotional, relational and strategic elements that collectively generate a unique set of associations in the public's mind" (Aaker, 1996, p. 68). Brand names are also a source of differentiation between an organisation and their competitors. When buying a product or a service, most of the customers buy according to the brand name that could give them the best value. Furthermore, brand names also help customers to recall the brand's benefits. However, if a brand name fails or leads to a negative perception, an organisation will face difficulties to reverse it (Aaker, 1996). As a result, brand name dilution or enhancement, either to prevent negative perceptions or to enhance existing equity, is of critical interest to organisations especially to the managers (Gurhan-Canli \& Maheswaran, 1998). Indirectly a brand name becomes the product's/services' inferences as well as evaluations (Heckler, Keller, Houston, \& Avery, 2014). Therefore, fashion retailers should acknowledge their brand names' contribution in communicating the brand because it could lead to brand loyalty.

H1: Brand name has a positive influence on brand loyalty.

Retailers offer a unique assortment of merchandise in their stores to maximise their appeal to customers. Customers identify a fashion retailer through their merchandise and make most of their purchase decisions based on these merchandise. Furthermore, cognitive factors such as the variety of merchandise, could lead to a positive customer behaviour especially in spending more money and time in a store (Donovan, Rossiter, Marcoolyn, \& Nesdale, 1994). Pan and Zinkhan (2006) had identified that assortment of merchandise was ranked highest by customers as compared to other factors in choosing a particular retailer. Morales, Kahn, 
McAlister, and Broniarczyk (2015) also confirmed that customer's attitudes and their possibility of shopping at a particular retail store especially fashion retail stores are positively linked to their view of the variety of merchandise available. Due to this, retail stores that can provide an assortment of merchandise for their customers will contribute to their store image, their store brand (Merrilees, Miller, \& Shao, 2016), and more importantly as a key determinant for future patronage of the retailer (Bauer, Kotouc, \& Rudolph, 2012). This could lead to the biggest influence towards customer satisfaction with the merchandise provided by the retailer (Kursunluoglu, 2014; Marques, Cardoso, \& Palma, 2013) and influence customer evaluations towards brand loyalty.

H2: Merchandise has a positive influence on brand loyalty.

Value-for-money is always linked with consumption (Grace \& O'Cass, 2005). Despite having some similarities, value-for-money differs from perceived value. Perceived value is customers' overall assessment of utility of a product based on perceptions of what is received and what is given (Zeithaml, 1988). In short, this assessment is a comparison between what the customer gets and what he/she has to give for a product or a service. However, the most common definition of value is the ratio or trade-off between quality and price which is a value for money conceptualisation (Sweeney \& Soutar, 2001). Value-for-money is the utility derived from the product due to the reduction of its perceived short- and long-term costs (Sweeney \& Soutar, 2001). From customers' perspective, a brand that has value-for-money is linked with the quality of the product that they purchase. In addition, brand and price are factors that customers will look into when there is lack of confidence in choosing the most appropriate alternative products (Suarez, Quinones, \& Yague, 2016). In other words, the "trade-off" between what is being sacrificed in enabling them to obtain what they want (Zeithaml, 1988). Therefore, customers' perceived value towards a product or a service could influence their purchase given that consumers have become more demanding and discerning in their purchase behaviour.

H3: Value-for-money has a positive influence on brand loyalty.

Servicescapes refer to the physical environment of a service business or a place where products are sold. This includes the space/function; signs, symbols, and artifacts; and ambient conditions of the environment (Raab, Zemke, Hertzman, \& Singh, 2013). More importantly, servicescapes influence consumers' emotional, cognitive, and psychological responses (Bitner, 1992; Sachdeva \& Goel, 2015). For example, retailers could break free from the standard design of servicescapes by creating more interactive, immersive, and authentic environments (Foster \& McLelland, 2015). Subsequently, these could influence consumer evaluations 
towards the retail environment experiences (Durna, Dedeoglu, \& Balikcioglu, 2015) and their behaviours. Therefore, if consumers have a great experience towards the servicescapes, it will influence them to return and be loyal towards the fashion retail store.

H4: Servicescapes have a positive influence on brand loyalty.

Employee service refers to the service provider's employees' behaviour, response, or performance while they are serving and assisting the customers (Liao \& Chuang, 2004). Customers will evaluate the employees' service quality and determine the worthiness to stay loyal towards the brand (Ramaseshan, Rabbanee, \& Burford, 2017). In other words, customers' perception of service quality of a retail store is highly reliant on the employees' activities and behaviour. Therefore, considering and meeting customers' expectations is very important in delivering good employee service. Research has identified that employee service has a positive effect on customer loyalty (Rabbanee, Burford, \& Ramaseshan, 2015).

H5: Employee service has a positive influence on brand loyalty.

Feelings play a very important role in consumer decision making especially in purchasing a fashionable brand. Furthermore, it has a profound effect on consumption experiences and consumer reaction (Babin \& Babin, 2001). There is, however, some distinction between feelings and emotions. While emotions are mental states of readiness that stem from the appraisals of events or one's own thoughts, feelings are perceived physical or mental sensations (Bagozzi, Gopinath, $\&$ Nyer, 1999). The arousal of positive feelings at the time of consumption has been shown to affect several brand outcomes in a positive way such as customers' brand choice, brand loyalty, and brand retention (O'Cass \& Grace, 2004). Therefore, if customers are feeling uncertain towards a brand, they are less likely to buy. Berry (2000) observed that retail brands need to make strong feeling connections with their customers. Customers who have stronger feelings for a brand will tend to trust a brand more. When trust occurs, customers will be emotionally reliant, and this will affect them when purchasing and using the brand (Dunn \& Schweitzer, 2005). Subsequently when customers' have positive feelings towards the brand, this may explain the condition that they would consider being loyal towards the brand.

H6: Feelings have a positive influence on brand loyalty.

Self-image congruence refers to the match between customers' self-concept and the user image of a given brand (Kressmann et al., 2006). In other words, customers will evaluate the brand based on the brand's user-image with their own 
self-concept. Accordingly, the higher the degree of congruence, the higher the intention to purchase will be. The consumption of a brand symbolises a person's attributes, motivations, and social patterns (Hosany \& Martin, 2012). To maintain one's self-image congruence, consumers will stay loyal towards the brand (Das, 2014). Hence, self-congruity could influence and play a very important role in customers' brand loyalty (Kressmann et al., 2006).

H7: Self-image congruence has a positive influence on brand loyalty.

Controlled communications in the form of advertising and promotions play a dominant role in establishing awareness and customers' attachment towards the brand (O'Cass \& Grace, 2004). It is a bridge that links the organisation's identity with the image of the company (He \& Mukherjee, 2009). According to Johan van Rekom (1997), control communications could improve a certain desired corporate image for target audience. For example, advertising plays a very important role especially in affecting customers' attitude, intentions as well as perceptions towards a product or service. Furthermore, advertising also includes corporate logo, which is important for product and corporate companies because it helps customers reduce their doubts and uncertainties, creating future purchase intentions, and more importantly convey a favourable brand image when compared to their competitors. Since controlled communications will influence customers' evaluation of brand dimensions, therefore, controlled communications delivered by retailers to their customers ought to be relevant (Krystallis \& Chrysochou, 2014).

H8: Controlled communications have a positive influence on brand loyalty.

Similar to controlled communications, uncontrolled communications in the likes of word-of-mouth, non-paid publicity, or tertiary communication have the same important role in influencing customers' awareness and attachment towards the brand (O'Cass \& Grace, 2004; Melewar, Foroudi, Gupta, Kitchen, \& Foroudi, 2017). Uncontrolled communications can exert either positive or negative impact towards a retailer's brand. In other words, uncontrolled communications will have either positive or negative effect towards customer evaluations of the brand. Moreover, customers tend to believe uncontrolled communications more than controlled communications because the comments or the publicity that are given by other customers or parties are their pre-purchase expectation of the brand and post-purchase experience with the brand (O'Cass \& Grace, 2004). This indirectly will challenge the dynamics of the retailers' brand. Therefore, uncontrolled communications have the power to influence customers' brand loyalty tendencies.

H9: Uncontrolled communications have a positive influence on brand loyalty. 


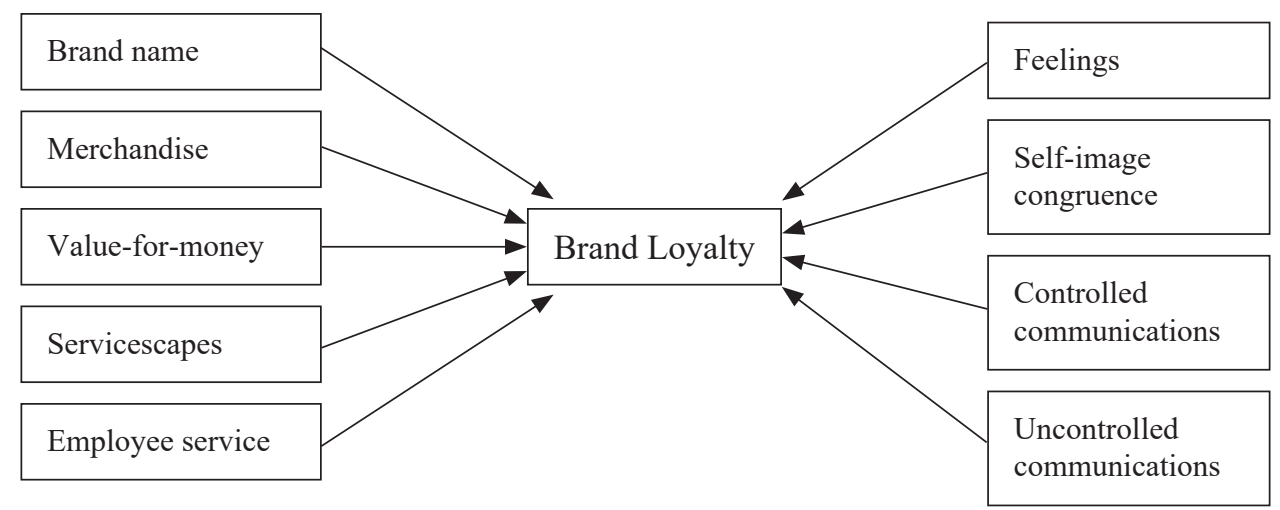

Figure 1. Research framework

\section{METHODOLOGY}

\section{Population and Sample}

The population of this study concerns Uniqlo customers in Malaysia. Specifying the entire population of Uniqlo customers in Malaysia would not be possible, as they would not all be known and access will be difficult. For this reason, a nonprobability sampling method, particularly purposive sampling, was used whereby consumers who have experienced Uniqlo before would be targeted. This meant that consumers would have to be aware of the Uniqlo brand name and have at least visited the stores before they can qualify as respondents for this study. From there on, a snowball sampling method (which is a subset of purposive sampling) was applied in which the respondent was asked to suggest someone else such as their family members and friends whom they know would be appropriate respondents for the study (i.e., being Uniqlo customers). Consumers were approached and surveyed mainly via two methods: face-to-face and online. In this way, respondents would be able to concentrate better on answering the survey as opposed to a mallintercept method where noise and other distractions are most likely to impair survey completion. The data collection via face-to-face method was conducted mainly in Penang, Kuala Lumpur, and Selangor. These are the most urban, populous areas in Malaysia where there is high purchasing power and brand savviness among the consumers. In addition, the number of Uniqlo stores are also high in these three areas (total of 27 stores). A total of 309 usable responses were obtained from the sampling exercise and used for the analysis. 


\section{Instrument}

The survey of Uniqlo customers was carried out using a self-administered questionnaire. Prior to the data collection, a pre-test was carried out to ensure that the questionnaire was comprehensible. Confusing or unclear words and statements were removed at this point. The finalised questionnaire for data collection was made up of several sections. The first section queried the demographic details of the respondents such as their gender, ethnicity, and age group. The subsequent sections inquired the respondents' shopping experience with Uniqlo such as their purchase frequency and also their experience with Uniqlo across a range of branding aspects. Altogether, respondents spent approximately 10 to 15 minutes answering the questionnaire.

\section{Measures}

Two primary sides of branding aspects were examined namely brand evidence (Brand Name, Merchandise, Value-for-Money, Servicescapes, Employee Service, Feelings, Self-Image Congruence) and brand hearsay (Controlled Communications such as advertising and promotions, Uncontrolled Communications such as publicity and word-of-mouth) along with the outcome of the branding aspects which was assessed via brand loyalty. The items/measures of the branding aspects in the questionnaire were adapted from the measures in SBVM (Grace \& O'Cass, 2005). Brand Name, Merchandise, Value-for-Money, Servicescapes, Employee Service, Controlled Communications and Uncontrolled Communications were measured using a 7-point Likert scale ranging from $1=$ strongly disagree to $7=$ strongly agree. On the other hand, Feelings, Self-Image Congruence, and Brand Loyalty were measured on a 5-point Likert scale ranging from $1=$ definitely disagree to $5=$ definitely agree.

\section{Data Analysis}

Two analysis software packages were utilised for the analysis of data. SPSS 20 was used to compute the descriptive statistics (frequencies, percentages) for the respondents' demographic profile while SmartPLS 3.2.6 (Ringle, Wende, \& Becker, 2015) was used for the partial least squares analysis of this study's measurement model and structural model. Following Anderson and Gerbing's (1988) recommended two-stage analytical procedure, the measurement model was tested prior to the testing of the structural model. The validity and reliability of the measurement model had to be established first before proceeding to examine the structural model for the hypothesised relationships. 


\section{RESULTS}

\section{Respondents' Demographic Profile}

Out of 309 respondents, majority were females (64.4\%). A high percentage were Millennials, as those who fell under the 18-29-year-olds group constitute $77.3 \%$ of the respondents. This was followed by respondents who were aged between 30-39-year-olds (13.9\%), 40-49-year-olds (6.5\%), and finally 50-59-year-olds $(2.3 \%)$. Given that Malaysia is a multiracial country, respondents were of different ethnicities. The Chinese constitute $58.3 \%$ of the respondents followed by the Malays at $36.9 \%$, and the Indians at $4.9 \%$. Most of them had at least a bachelor's degree $(43.4 \%)$. The remaining respondents had at least some secondary school education $(5.2 \%)$, pre-university or matriculation qualification $(27.2 \%)$, a certificate or diploma (19.4\%), or a master's degree and above (4.9\%).

\section{Common Method Bias}

Common method bias is a serious issue in management research in which the variance is attributed to measurement method rather than variance explained by the study's constructs. The measurement items in this study were tested for bias using the Harman's single factor test. Through the principle components factor analysis, the principal factor explained was $31.76 \%$ showing no indications of common method bias given that the principal factor did not account for a majority of variance explained. In short, the percentage of variance explained for a single (principal) component in the factor analysis does not exceed 50\% (Podsakoff \& Organ, 1986).

\section{Measurement Model}

Prior to hypothesis testing, the measurement model of this study had to be assessed for its convergent and discriminant validity. The measurement model consists of relationships among the latent constructs of interests and the measures (indicators) underlying each construct. Thus it is important to establish whether the indicators reflect their underlying constructs. Table 1 lists the indicator loadings, average variance extracted (AVE), and composite reliability scores for all the constructs in the measurement model. 
Table 1

Convergent validity of the measurement model

\begin{tabular}{|c|c|c|c|c|}
\hline Construct & Indicators & $\begin{array}{l}\text { Indicator } \\
\text { loadings }\end{array}$ & $\mathrm{AVE}^{\mathrm{a}}$ & $\begin{array}{l}\text { Composite } \\
\text { reliability }\end{array}$ \\
\hline \multirow[t]{3}{*}{ Brand name } & U_brandname1 & 0.857 & \multirow[t]{3}{*}{0.774} & \multirow[t]{3}{*}{0.911} \\
\hline & $\mathrm{U}$ brandname 2 & 0.908 & & \\
\hline & U_brandname3 & 0.873 & & \\
\hline \multirow[t]{3}{*}{ Controlled communications } & U_controlledcom 1 & 0.877 & \multirow[t]{3}{*}{0.823} & \multirow[t]{3}{*}{0.933} \\
\hline & U_controlledcom 2 & 0.926 & & \\
\hline & U_controlledcom3 & 0.917 & & \\
\hline \multirow{3}{*}{ Employee service } & U_employees 1 & 0.908 & \multirow[t]{3}{*}{0.8} & \multirow[t]{3}{*}{0.923} \\
\hline & U_employees2 & 0.889 & & \\
\hline & U_employees3 & 0.887 & & \\
\hline \multirow[t]{3}{*}{ Feelings } & U_feelings1 & 0.89 & \multirow[t]{3}{*}{0.812} & \multirow[t]{3}{*}{0.929} \\
\hline & U_feelings2 & 0.904 & & \\
\hline & U_feelings3 & 0.91 & & \\
\hline \multirow[t]{3}{*}{ Merchandise } & U_merchandise 1 & 0.862 & \multirow[t]{3}{*}{0.717} & \multirow[t]{3}{*}{0.884} \\
\hline & U_merchandise2 & 0.868 & & \\
\hline & U_merchandise 3 & 0.809 & & \\
\hline \multirow[t]{3}{*}{ Self-image congruence } & U_selfimage1 & 0.849 & \multirow[t]{3}{*}{0.712} & \multirow[t]{3}{*}{0.881} \\
\hline & U_selfimage2 & 0.843 & & \\
\hline & U_selfimage3 & 0.839 & & \\
\hline \multirow[t]{3}{*}{ Servicescapes } & U_servicescape1 & 0.894 & \multirow[t]{3}{*}{0.778} & \multirow[t]{3}{*}{0.913} \\
\hline & U_servicescape2 & 0.86 & & \\
\hline & U_servicescape 3 & 0.892 & & \\
\hline \multirow[t]{4}{*}{ Uncontrolled communications } & U_uncontrolledcom 1 & 0.825 & \multirow[t]{4}{*}{0.718} & \multirow[t]{4}{*}{0.911} \\
\hline & U_uncontrolledcom2 & 0.836 & & \\
\hline & U_uncontrolledcom3 & 0.867 & & \\
\hline & U_uncontrolledcom4 & 0.861 & & \\
\hline \multirow[t]{3}{*}{ Value-for-money } & U_value1 & 0.858 & \multirow[t]{3}{*}{0.779} & \multirow[t]{3}{*}{0.914} \\
\hline & U_value2 & 0.908 & & \\
\hline & U_value3 & 0.881 & & \\
\hline \multirow[t]{3}{*}{ Brand loyalty } & U_verdict1 & 0.938 & \multirow[t]{3}{*}{0.855} & \multirow[t]{3}{*}{0.947} \\
\hline & U_verdict2 & 0.922 & & \\
\hline & U_verdict3 & 0.914 & & \\
\hline
\end{tabular}

Notes:

a $\mathrm{AVE}=$ (summation of squared factor loadings) / (summation of squared factor loadings) (summation of error variances)

${ }^{\mathrm{b}}$ Composite reliability $=$ (square of the summation of the factor loadings) $/$ [(square of the summation of the factor loadings) + (square of the summation of the error variances)] 
All indicator loadings were above 0.70 ranging from a lower bound of 0.809 to an upper bound of 0.938 . The composite reliabilities of the latent constructs ranged from 0.881 to 0.947 ; exceeding the threshold value of 0.70 recommended by Hair, Hult, Ringle, and Sarstedt (2017). The AVE for each construct exceeded the recommended value of 0.50 suggested by Fornell and Larcker (1981), indicating that on average the construct explains more than half of the variance of its indicators (Hair et al., 2017). Apart from that, the variance inflation factor (VIF) scores for all the constructs were within the acceptable threshold of 5 (Hair et al., 2017). In short, there is sufficient evidence to conclude that convergent validity was achieved.

Discriminant validity which is the extent to which a construct is truly distinct from other constructs (Hair et al., 2017) is commonly established using the Fornell-Larcker criterion. Under this criterion, the square root of the AVE values are compared with the latent variable correlations (Hair et al., 2017). However, according to Henseler, Ringle, and Sarstedt (2015), the commonly-applied FornellLarcker criterion has a low sensitivity meaning that discriminant validity problems can sometimes go undetected. Hence, a better approach is used in this study to evaluate the measurement model for discriminant validity which is the HeterotraitMonotrait Ratio of Correlations (HTMT). Based on the HTMT results in Table 2, none of the inter-construct correlations were above 0.85 , thereby complying with the conservative $\mathrm{HTMT}_{.85}$ criterion (Henseler et al., 2015). In addition, none of the HTMT confidence intervals include a value of 0 . Hence, the HTMT results proved that all the constructs in the measurement model are conceptually distinct from each other.

Table 2

Discriminant validity of the measurement model

\begin{tabular}{lcccccccccc}
\hline & BR & CC & EM & FE & ME & LO & IM & SE & UC & VA \\
\hline BR & & & & & & & & & & \\
CC & 0.523 & & & & & & & & & \\
EM & 0.326 & 0.592 & & & & & & & & \\
FE & 0.414 & 0.464 & 0.496 & & & & & & \\
ME & 0.524 & 0.573 & 0.579 & 0.706 & & & & & \\
LO & 0.396 & 0.53 & 0.418 & 0.747 & 0.7 & & & & \\
IM & 0.561 & 0.437 & 0.297 & 0.714 & 0.574 & 0.685 & & & & \\
SE & 0.334 & 0.578 & 0.761 & 0.483 & 0.613 & 0.45 & 0.228 & & & \\
UC & 0.492 & 0.71 & 0.467 & 0.512 & 0.558 & 0.576 & 0.539 & 0.414 & & \\
VA & 0.473 & 0.54 & 0.457 & 0.561 & 0.849 & 0.636 & 0.559 & 0.533 & 0.526 & \\
\hline
\end{tabular}

Note: $\mathrm{BR}=$ Brand Name; $\mathrm{CC}=$ Controlled Communications; $\mathrm{EM}=$ Employee Service; FE = Feelings; $\mathrm{ME}=$ Merchandise LO = Brand Loyalty; $\mathrm{IM}=$ Self-Image Congruence; $\mathrm{SE}=$ Servicescapes; $\mathrm{UC}=$ Uncontrolled Communications; VA = Value-for-Money 


\section{Structural Model}

With the validity of the measurement model established, the structural model comprising the hypothesised relationship between exogenous (independent) and endogenous (dependent) variables in the model was then examined. Bootstrapping was applied to obtain the path coefficients and their corresponding t-values. Consequently inferences would be drawn by determining the statistical significance of each path's t-value. A bootstrapping procedure of 1,000 samples was applied to acquire more stable results. Table 3 lists all path coefficients, their corresponding t-values, and verdict for each hypothesised path.

Table 3

Results of the structural model

\begin{tabular}{lclllc}
\hline Relationship & Std. Beta & t-value & \multicolumn{1}{c}{ Decision } & $\mathrm{f}^{2}$ & VIF \\
\hline $\mathrm{H} 1: \mathrm{BR} \rightarrow$ LO & -0.074 & $1.92^{*}$ & Not supported & 0.01 & 1.526 \\
$\mathrm{H} 2: \mathrm{ME} \rightarrow$ LO & 0.143 & $2.14^{*}$ & Supported & 0.02 & 2.677 \\
$\mathrm{H} 3: \mathrm{VA} \rightarrow$ LO & 0.127 & $1.96^{*}$ & Supported & 0.02 & 2.264 \\
$\mathrm{H} 4: \mathrm{SE} \rightarrow$ LO & 0.056 & 0.93 & Not supported & 0.00 & 2.129 \\
$\mathrm{H} 5: \mathrm{EM} \rightarrow$ LO & -0.054 & 1.06 & Not supported & 0.00 & 2.032 \\
$\mathrm{H} 6: \mathrm{FE} \rightarrow$ LO & 0.329 & $5.54^{* *}$ & Supported & 0.12 & 2.127 \\
H7: IM $\rightarrow$ LO & 0.216 & $3.39^{* *}$ & Supported & 0.06 & 1.983 \\
$\mathrm{H} 8: \mathrm{CC} \rightarrow$ LO & 0.093 & 1.46 & Not supported & 0.01 & 2.134 \\
H9: UC $\rightarrow$ LO & 0.119 & $2.04^{*}$ & Supported & 0.02 & 1.893 \\
\hline
\end{tabular}

Note: ${ }^{*} p<0.05 ;{ }^{* *} p<0.01 ;{ }^{\Psi}$ not supported due to contrasting directions of the hypothesised relationship

Out of all the branding aspect variables, merchandise $(\beta=0.143, p<0.05)$, value-for-money $(\beta=0.127 ; p<0.05)$, feelings $(\beta=0.329 ; p<0.01)$, self-image congruence $(\beta=0.216 ; p<0.01)$, and uncontrolled communications $(\beta=0.119$; $p<0.05)$ exhibited a significant, positive impact on brand loyalty. Following Cohen's (1988) criteria for effect sizes whereby $f^{2}$ values of $0.02,0.15$, and 0.35 indicate an exogenous construct's small, medium, or large effect, respectively on an endogenous construct, all the positive and significant variables were found to exert small effect on brand loyalty, with feelings $\left(f^{2}=0.12\right)$ having the highest impact, followed by self-image congruence $\left(\mathrm{f}^{2}=0.06\right)$, merchandise $\left(\mathrm{f}^{2}=0.02\right)$, valuefor-money $\left(\mathrm{f}^{2}=0.02\right)$, and lastly uncontrolled communications $\left(\mathrm{f}^{2}=0.02\right)$. Hence, only $\mathrm{H} 2, \mathrm{H} 3, \mathrm{H} 6, \mathrm{H} 7$, and H9 were supported. On the other hand, servicescapes, employee service, and controlled communications did not show any significant impact on brand loyalty. Though the effect of brand-name on brand loyalty $(\beta=-0.074 ; p<0.05)$ was found to be significant, the effect itself is a negative 
one, contrary to what was hypothesised. Owing to this, H1 was not supported. It was revealed that $59 \%\left(\mathrm{R}^{2}=0.590\right)$ of variance in brand loyalty can be explained by the model which is deemed adequate by Falk and Miller's (1992) standards considering that an $\mathrm{R}^{2}$ must be at least 0.10 .

\section{CONCLUSION}

This study set out to determine which of Uniqlo's branding aspects contribute to building its brand loyalty among customers. The findings of the study showed very distinctly that the significant aspects were merchandise, value-for-money, feelings, self-image congruence, and uncontrolled communications. The beta values in the analysis indicated that feelings had the strongest impact on brand loyalty followed by self-image congruence, merchandise, value-for-money, and finally uncontrolled communications. In contrast, Grace and O'Cass (2005) found that servicescapes of all the brand dimensions had the strongest contribution to a customers' experience or usage of the brand. Nevertheless from the findings of their study, Grace and O'Cass (2005) acknowledged that branding dimensions experienced at the time of consumption such as core service, feelings, and value-for-money were significant and salient dimensions that make up customers' interaction with the brand, just as how this study confirmed the importance of merchandise (the core aspect), value-for-money, and feelings in customers' experience with the brand. Similarly, Krystallis and Chrysochou (2014) found in their study of the airline service that core service, value-for-money, feelings, and self-image congruence were the most important brand components that form consumers' perception of their chosen brand.

The importance of feelings in consumer decision making and its effect on consumption experiences and consumer reactions have long since been acknowledged by scholars (Babin \& Babin, 2001). Compared to cold cognition which involves logical and rational thinking in product evaluations, hot cognition which involves emotional influence on decision making seem to exert a stronger impact or brand loyalty (Kunda, 1990; Roiser \& Sahakian, 2013). This could explain the reason of the relationship between feelings and brand loyalty being comparatively more intense than other branding aspects in this study. To the customers, Uniqlo offers a unique shopping experience that delights them; making them happy and pleased to the extent that they are more than willing to revisit and repurchase from Uniqlo.

Next to feelings, self-image congruence accounts for the second highest impact on brand loyalty. Keller states that user imagery whereby consumers' perception of 
the type of person who uses the product or service is a crucial element in building consumers' resonance with the particular brand of the product or service. From this study, it is evident that customers of Uniqlo could relate very much to Uniqlo's brand personality (identity) - basic, timeless yet stylish. As classic research has proven, the more similarity consumers can see between a brand's user image and the characteristics of their own actual or ideal self, the more preference they will develop for the brand (Belk, 1985; O'Cass \& Lim, 2001; Quester, Dzever, \& Chetty, 2000; Sirgy, 1986).

Subsequently merchandise had the third most impact on customers' loyalty towards Uniqlo. Given that Uniqlo is in the business of selling apparel and accessories, naturally consumers' evaluation of aspects relating to its merchandise such as its product quality, variety, and suitability play a determining role in whether they will revisit, repurchase, or recommend the brand to others. As consumers become savvier, they tend to demand more value for the money that they pay to obtain a product or service. Ideally, benefits obtained should exceed the amount of money that they spend on their purchases. The consumers surveyed definitely felt that Uniqlo's merchandise and service provided value-for-money to the extent that they are willing to continuously repatronise the stores.

Millennials tend to view a company's controlled communications such as its paid advertising with caution. In some instances, they are unlikely to respond to advertisements or other marketing type at all (Hawkins \& Mothersbaugh, 2014). This may well explain why the impact of controlled communications on brand loyalty was not found to be significant. However, they respond more favourably to other forms of communications such as the publicity generated by third parties like journalists' review articles and bloggers' reviews as well as word-of-mouth recommendations because these uncontrolled communications are regarded as more authentic and trustworthy. Millennials, who made up the majority of respondents in this study have certainly shown a strong preference for uncontrolled communications which has been proven to contribute to their loyalty towards Uniqlo.

With regard to the inverse relationship found between brand name and brand loyalty, it can be explained by the fact that consumers may grow to become disinterested in a particular brand should it settle to become very predictable through time, subsequently this could lead them to seek out other clothing brands as well. Krystallis and Chrysochou (2014) who found that the insignificance of the brand name in shaping the brand evidence construct could be attributed to inconsistency of service delivered to the customers which consequentially heightens customers' perceived risk associated with the brand name. 
In terms of employee service, the degree of courtesy, friendliness, helpfulness, and knowledge of the personnel in the store may still vary from person to person and from one occasion to the other, therefore the positive impact of this variable on brand loyalty was not evident. No doubt servicescapes or physical surroundings of a store contribute to the overall brand experience encountered by consumers, however in this case, it was not enough to retain customers and give them a reason to keep returning to Uniqlo.

To successfully attain customers' loyalty, a brand needs to ensure that it strikes both the head and the heart of the consumer. Building intense and active loyalty is a function of both the performance of the brand's products/service and the imagery of the brand which is how the brand is thought of by consumers in abstract terms (Keller, 2013). In other words, both tangible and rational aspects of a brand need to integrate with the intangible and emotional aspects. Uniqlo has undeniably high quality merchandise sold in ambient stores supported by customer service, but what eventually won the affinity and loyalty of Malaysian consumers towards its brand was how it made them feel happy, pleased, and impressed. For its brand to continue resonating well among consumers, Uniqlo should focus on tapping more into the consumer emotions (e.g., warmth, fun, excitement, self-respect, social approval or security) through the use of promotional campaigns which apply transformational appeals (Naylor, Kleiser, Baker, \& Yorkston, 2008). In doing so, it is pertinent that Uniqlo continues to showcase itself as a brand that caters to the needs of the modern, 21st century consumer who desires functionality without compromising style. At the same time, the rational aspects of the brand through the quality and variety of the merchandise sold and its value-for-money attribute should be maintained.

This study focused on Uniqlo customers in general without considering them according to their different demographic characteristics such as gender, age, and ethnicity. Though simple, demographic characteristics can provide rich insights that help in making strategic segmentation, targeting, and positioning decisions. As an extension to this study, future studies may identify which key brand loyalty drivers are important to the particular groups of consumers (e.g., males vs. females; Generation X, Y, and Z). Future studies can also consider the inclusion of third variables such as mediators or moderators to expand the research framework on SBVM. For instance, customers' familiarity towards the brand and customer involvement can be added as moderators given that these are important aspects that could influence service branding and corresponding consumers' decision-making and behaviour (Brodie, Whittome, \& Brush, 2009; Chernatony \& Riley, 1998; Krystallis \& Chrysochou, 2014). 


\section{ACKNOWLEDGEMENTS}

The authors would like to thank The Sumitomo Foundation for supporting this study under the Grant for Japan-related Research Projects [304/PMGT/650768/ S139].

\section{APPENDIX}

The brand name tells me a lot about what to expect from it. (U_brandname1)

The brand name means something to me. (U brandname2)

The brand name tells me everything I need to know about its products. (U_brandname3)

This brand's products suit my needs. (U_merchandise1)

This brand's products are of high quality. (U_merchandise2)

This brand has a wide selection/variety of products. (U_merchandise3)

This brand's products are reasonably priced. (U_value1)

This brand's products offer value for money. (U_value2)

This brand's products provide good quality for the price. (U_value3)

The physical environments in the brand's stores are comfortable (e.g. lighting, music)

(U_servicescape1)

The employees in this brand's stores are neat and well-dressed. (U_servicescape2)

The products sold in this brand's stores are organized and displayed attractively.

(U_servicescape3)

The employees in this brand's stores are helpful. (U_employees1)

The employees in this brand's stores are knowledgeable. (U_employees2)

The employees in this brand's stores are friendly. (U_employees3)

The advertising and promotions of this brand are good. (U_controlledcom1)

The advertising and promotions of this brand are effective. (U_controlledcom2)

I like this brand's advertising and promotions. (U_controlledcom3)

Publicity about this brand has been significant in affecting my views of this brand.

(U_uncontrolledcom1)

Publicity about this brand influenced my evaluation of this brand. (U_uncontrolledcom2)

My friends'/family's opinions have been significant in affecting my view of this brand.

(U_uncontrolledcom3)

My friend's/family's opinions about this brand influenced my evaluation of this brand.

(U_uncontrolledcom4) 
The image of this brand is consistent with my own self-image. (U_selfimage1)

The kind of person who usually shops at this brand is very much like me. (U_selfimage2)

Using this brand reflects who I am. (U_selfimage3)

I am likely to visit this brand's store in future. (U_verdict1)

I will possibly purchase this brand's products in future. (U_verdict2)

I will recommend this brand to others. (U_verdict3)

My experience with this brand makes me feel:

Impressed (U_feelings1)

Happy (U_feelings2)

Pleased (U_feelings3)

\section{REFERENCES}

Aaker, D.A. (1996). Building strong brands. New York: Free Press.

Anderson, J.C., \& Gerbing, D.W. (1988). Structural equation modeling in practice: A review and recommended two-step approach. Psychological Bulletin, 103(3), 411-423. https://doi.org/10.1037/0033-2909.103.3.411

Babin, B.J., \& Babin, L. (2001). Seeking something different? A model of schema typicality, consumer affect, purchase intentions and perceived shopping value. Journal of Business Research, 54(2), 89-96. https://doi.org/10.1016/S01482963(99)00095-8

Bagozzi, R., Gopinath, M., \& Nyer, P. (1999). The role of emotions in marketing. Journal of the Academy of Marketing Science, 29(2), 184-206. https://doi. org/10.1177/0092070399272005

Bauer, J.C., Kotouc, A.J., \& Rudolph, T. (2012). What constitutes a good assortment? A scale for measuring consumer's perceptions of an assortment offered in a grocery category. Journal of Retailing and Consumer Service, 19(1), 11-26. https://doi.org/10.1016/j.jretconser.2011.08.002

Belk, R.W. (1985). Materialism: Trait aspects of living in the material world. Journal of Consumer Research, 12(3), 265-280. https://doi.org/10.1086/208515

Berry, L.L. (2000). Cultivating service brand equity. Journal of the Academy of Marketing Science, 28(1), 128-137. https://doi.org/10.1177/0092070300281012

Bitner, M.J. (1992). Servicespaces: The impact of physical surroundings on customers and employees. Journal of Marketing, 56(2), 57-71. https://doi.org/10.2307/1252042

Brodie, R.J., Whittome, J.R.M., \& Brush, G.J., (2009). Investigating the service brand: A customer value perspective. Journal of Business Research, 62(3), 345-355. https://doi.org/10.1016/j.jbusres.2008.06.008

CEIC. (2017). Malaysia private consumption: \% of GDP. Retrieved 15 May 2017 from https://www.ceicdata.com/en/indicator/malaysia/private-consumption--ofnominal-gdp. 
Chernatony, L., \& Riley, F.D. (1998). Defining a brand: Beyond the literature with experts' interpretations. Journal of Marketing Management, 14(5), 417-443. https://doi. org/10.1362/026725798784867798

Cohen, J.E. (1988). Statistical power analysis for the behavioral sciences. Hillsdale, NJ: Lawrence Erlbaum Associates, Inc. https://doi.org/10.1002/bs.3830330104

Das, G. (2014). Impacts of retail brand personality and self-congruity on store loyalty: The moderating role of gender. Journal of Retailing and Consumer Services, 21(2), 130-138. https://doi.org/10.1016/j.jretconser.2013.07.011

Donovan, R.J., Rossiter, J.R., Marcoolyn, G., \& Nesdale, A. (1994). Store atmosphere and purchasing behavior. Journal of Retailing, 70(3), 283-294. https://doi.org/ 10.1016/0022-4359(94)90037-X

Dunn, J., \& Schweitzer, M. (2005). Feeling and believing: The influence of emotion on trust. Journal of Personality and Social Psychology, 88(5), 736-748. https://doi. org/10.1037/0022-3514.88.5.736

Durna, U., Dedeoglu, B.B., \& Balikcioglu, S. (2015). Image perceptions of customers on behavioral intentions in the hotel industry. International Journal of Contemporary Hospitality Management, 27(7), 1728-1748. https://doi.org/10.1108/IJCHM-042014-0173

Economic Transformation Programme (ETP). (2015). Annual report 2015. Retrieved 15 May 2017 from https://www.pemandu.gov.my/assets/publications/ annualreports/ENG_PEMANDU_NTP_AR2015_260416.pdf

Economic Transformation Programme (ETP). (2014). Annual report 2014. Retrieved 15 May 2017 from http://etp.pemandu.gov.my/annualreport2014/upload/06 NKEA04_ENG_WSR.pdf

Euromonitor International. (January 2017). Retailing in Malaysia. Retrieved 15 May 2017 from http://www.euromonitor.com/retailing-in-malaysia/report

Euromonitor International. (March 2017a). Menswear in Malaysia. Retrieved 15 May 2017 from http://www.euromonitor.com/menswear-in-malaysia/report

Euromonitor International. (March 2017b). Womenswear in Malaysia. Retrieved 15 May 2017 from http://www.euromonitor.com/womenswear-in-malaysia/report

Falk, F.R., \& Miller, N.B. (1992). A premier for soft modeling. Akron, OH: University of Akron Press.

Fornell, C., \& Larcker, D.F. (1981). Evaluating structural equation models with unobservable variables and measurement error. Journal of Marketing Research, 18(1), 39-50. https://doi.org/10.2307/3151312

Foster, J., \& McLelland, M. (2015). Retail atmospherics: The impact of a brand dictated theme. Journal of Retailing and Consumer Services, 22, 195-205. https://doi. org/10.1016/j.jretconser.2014.07.002

Grace, D., \& O’Cass, A. (2005). Service branding: Consumer verdicts on service brands. Journal of Retailing and Consumer Services, 12(2), 125-139. https://doi.org/ 10.1016/j.jretconser.2004.05.002

Gurhan-Canli, Z., \& Maheswaran, D. (1998). The effect of extensions on brand name dilution and enhancement. Journal of Marketing Research, 35(4), 464-473. https://doi.org/10.2307/3152165 
Hair, J.F., Hult, G.T.M., Ringle, C.M., \& Sarstedt, M. (2017). A primer on partial least squares structural equation modeling (PLS-SEM). Los Angeles: Sage Publication.

Hawkins, D.I., \& Mothersbaugh, D.L. (2014). Consumer behavior: Building marketing strategy (12th ed.). New York: McGraw-Hill.

Heckler, S., Keller, K., Houston, M., \& Avery, J. (2014). Building brand knowledge structures: Elaboration and interference effects on the processing of sequentially advertised brand benefit claims. Journal of Marketing Communication, 20(3), 176-196. https://doi.org/10.1080/17544750.2012.660766

He, H.W., \& Mukherjee, A. (2009). Corporate identity and consumer marketing: A process model and research agenda. Journal of Marketing Communication, 15(1), 1-16. https://doi.org/10.1080/13527260802018041

Henseler, J., Ringle, C.M., \& Sarstedt, M. (2015). A new criterion for assessing discriminant validity in variance-based structural equation modelling. Journal of the Academy of Marketing Science, 43(1), 115-135. https://doi.org/10.1007/s11747-0140403-8

Hosany, S., \& Martin, D. (2012). Self-image congruence in consumer behavior. Journal of Business Research, 65(5), 685-691. https://doi.org/10.1016/j.jbusres.2011.03.015

Interbrand. (2014). Japan's Best Global Brands 2014: Executive summary. Retrieved 10 May 2017 from http://www.rankingthebrands.com/PDF/Interbrand\%20 Japans\%20Best\%20 Global\%20Br ands\%202014.pdf

Jacoby, J., \& Chestnut, R. (1978). Brand loyalty: Measurement and management. New York: John Wiley \& Sons.

Keller, K.L. (2013). Strategic brand management: Building, measuring and managing brand equity (global ed.; 4th ed.). England: Pearson.

Kressmann, F., Sirgy, M.J., Herrmann, A., Huber, F., Huber, S., \& Lee, D.J. (2006). Direct and indirect effects of self-image congruence on brand loyalty. Journal of Business Research, 59, 955-964. https://doi.org/10.1016/j.jbusres.2006.06.001

Krystallis, A., \& Chrysochou, P. (2014). The effect of service brand dimensions on brand loyalty. Journal of Retailing and Consumer Services, 21, 139-147. https://doi. org/10.1016/j.jretconser.2013.07.009

Kunda, Z. (1990). The case for motivated reasoning. Psychological Bulletin, 108(3), 480498. https://doi.org/10.1037/0033-2909.108.3.480

Kursunlouglu, E. (2014). Shopping centre customer service: Creating customer satisfaction and loyalty. Marketing Intelligence \& Planning, 32(4), 528-548. https://doi. org/10.1108/MIP-11-2012-0134

Liao, H., \& Chuang, A. (2004). A multilevel investigation of factors influencing service performance and customer outcomes. Academy of Management Journal, 47(1), 41-58. https://doi.org/10.5465/20159559

Marques, S.H., Cardoso, M.M., \& Palma, A.P. (2013). Environmental factors and satisfaction in a specialty store. The International Review of Retail, Distribution and Consumer Research, 23(4), 456-474. https://doi.org/10.1080/09593969.201 3.785442

Marticotte, F., Arcand, M., \& Baudry, D. (2016). The impact of brand evangelism on oppositional referrals towards a rival brand. Journal of Product \& Brand Management, 25(6), 538-549. https://doi.org/10.1108/JPBM-06-2015-0920 
Melewar, T.C., Foroudi, P., Gupta, S., Kitchen, P.J., \& Foroudi, M. (2017). Integrating identity, strategy and communications for trust, loyalty and commitment. European Journal of Marketing, 51(3), 572-604. https://doi.org/10.1108/EJM08-2015-0616

Melody, G. (2016). Uniqlo expands its business further. Retrieved 10 May 2017 from https://www.pressreader.com/malaysia/the-star-malaysia-star2/20160720/ 282166470531164

Merrilees, B., Miller, D., \& Shao, W. (2016). Mall brand meaning: An experiential branding perspective. Journal of Product and Brand Management, 25(3), 262-273. https://doi.org/10.1108/JPBM-05-2015-0889

Morales, A., Kahn, B.E., McAlister, L., \& Broniarczyk, S. (2005). Perceptions of assortment variety: The effects of congruency between consumer internal and retailers. Journal of Retailing, 81(2), 156-169. https://doi.org/10.1016/j.jretai.2005.03.007

Naylor, G., Kleiser, S., Baker, J., \& Yorkston, E.A. (2008). Using transformational appeals to enhance the retail experience. Journal of Retailing, 84(1), 49-57. https://doi. org/10.1016/j.jretai.2008.01.001

O'Cass, A., \& Grace, D. (2004). Service brands and communication effects. Journal of Marketing Communications, 10(4), 241-254. https://doi. org/10.1080/1352726042000228286

O'Cass, A., \& Lim, K., (2001). The influence of brand associations on brand preference and purchase intention: An Asian perspective on brand associations. Journal of International Consumer Marketing, 14(2), 41-71.

Oliver, R.L. (1999). Whence consumer loyalty? Journal of Marketing, 63(Special Issue 1999), 33-34.

Pan, Y., \& Zinkhan, G.M. (2006). Determinants of retail patronage: A meta-analytical perspective. Journal of Retailing, 82(3), 229-243. https://doi.org/10.1016/j. jretai.2005.11.008

Podsakoff, P.M., \& Organ, D.W. (1986). Self-reports in organizational research: Problems and prospects. Journal of Management, 12(4), 531-544. https://doi. org/10.1177/014920638601200408

Quester,P.G., Dzever, S., \& Chetty, S.(2000). Country-of-origin effects on purchasing agents' product perceptions: An international perspective. Journal of Business \& Industrial Marketing, 15(7), 479-490. https://doi.org/10.1108/08858620010351706

Raab, C., Zemke, D.M., Hertzman, J.L., \& Singh, D. (2013). Restaurant customers' perceptions of noise and their satisfaction and loyalty behaviors. International Journal of Hospitality \& Tourism Administration, 14(4), 398-414. https://doi.org $/ 10.1080 / 15256480.2013 .838090$

Rabbanee, F. Burford, O., \& Ramaseshan, B. (2015). Does employee performance affect customer loyalty in pharmacy services? Journal of Service Theory and Practice, 25(6) 725-743. https://doi.org/10.1108/JSTP-06-2014-0126

Ramaseshan, B., Rabbanee, F., \& Burford, O. (2017). Combined effects of franchise management strategies and employee service performance on customer loyalty: A multilevel perspective. Journal of Strategic Marketing, 26(6), 479-497. https://doi.org/10.1080/0965254X.2017.1293137

Reichheld, F.F. (1996). The loyalty effect. Boston, MA: Harvard Business School Press. 
Ringle, C.M., Wende, S., \& Becker, J.M. (2015). SmartPLS 3. Bönningstedt: SmartPLS. Retrieved from http://www.smartpls.com

Roiser, J., \& Sahakian, B.J. (2013). Hot and cold cognition in depression. CNS Spectrums, 18(3), 1-11. https://doi.org/10.1017/S1092852913000072

Sachdeva, I., \& Goel, S. (2015). Retail store environment and customer experience: A paradigm. Journal of Fashion Marketing and Management, 19(3), 290-298. https://doi.org/10.1108/JFMM-03-2015-0021

Schiffman, L.G., \& Kanuk, L.L. (2014). Consumer behavior (11th ed.). Upper Saddle River, NJ: Prentice-Hall.

Sirgy, M.J. (1986). Self-congruity: Toward a theory of personality and cybernatics. New York: Praeger.

Suarez, M.G., Quinones, M., \& Yague, M.J. (2016). Store brand evaluative process in an international context. International Journal of Retail \& Distribution Management, 44(7), 754-771. https://doi.org/10.1108/IJRDM-11-2015-0168

Sweeney, J., \& Soutar, G. (2001). Consumer perceived value: The development of a multiple item scale. Journal of Retailing, 77(2), 203-220. https://doi.org/10.1016/ S0022-4359(01)00041-0

Temporal, P. (2000). Branding in Asia: The creation, development, and management of Asian brands for the global market. Singapore: John Wiley \& Sons.

Van Rekom, J. (1997). Deriving an operational measure of corporate identity. European Journal of Marketing, 31(5/6), 410-421. https://doi.org/10.1108/eb060640

Wallace, E., Buil, I., \& Chernatony, L. (2014). Consumer engagement with self-expressive brands: Brand love and WOM outcomes. Journal of Product and Brand Management, 23(1), 33-42. https://doi.org/10.1108/JPBM-06-2013-0326

Zeithaml, V.A. (1988). Consumer perceptions of price, quality and value: A means-end model and synthesis of evidence. Journal of Marketing, 52(1), 1-14. https://doi. org/10.2307/1251446 